\title{
Argumentointia monenlaisissa konteksteissa
}

Cornelia Ilie \& Giuliana Garzone (toim.): Argumentation across communities of practice. Multi-disciplinary perspectives. Argumentation in Context 10. Amsterdam: John Benjamins Publishing Company 2017. 345 s. ISBN 978-90-272-1127_9.

Cornelia Ilien ja Giuliana Garzonen toimittama teos Argumentation across communities of practice: Multi-disciplinary perspectives tarkastelee argumentointia, argumentaatioon pohjautuvia keskusteluja ja alakohtaisia argumentointikäytänteitä erilaisissa toimintayhteisöissä (community of practice). Toimintayhteisöllä tarkoitetaan ryhmää, joka muodostuu tietyn toiminnan ympärille ja jolla on omat kielelliset käytänteensä (ks. esim. Wenger 1998). Tarkastelun kohteena on esimerkiksi kielenkäyttö mediassa sekä oikeudellisissa, poliittisissa, yhteiskunnallisissa ja multimodaalisissa konteksteissa. Teoksessa yhdistyvät monenlaiset aineistot, teoreettiset näkökulmat ja tutkimusmetodit. Lähtökohtana on, että argumentaatio on sekä tilannesidonnaista että ihmiselle luontaista toimintaa.

Teos sisältää johdannon lisäksi 13 lukua. Luvut on ryhmitelty viiteen temaattiseen osaan, joista jokainen sisältää $2-3$ lukua. Ensimmäinen osa tarjoaa uusia näkökulmia argumentaation teoreettisiin lähtökohtiin, ja loput neljä osaa tarkastelevat argumentointikäytänteitä erilaisissa konteksteissa: toinen osa keskittyy poliittisiin konteksteihin, kolmas oikeuskonteksteihin, neljäs yhteiskunnallisiin ja perheen sisäisiin väittelyihin sekä viides multimodaalisiin ympäristöihin.

Teoksessa yhdistyvät retoriset, lingvistiset, filosofiset, kognitiiviset ja sosiologiset lähestymistavat. Eniten hyödynnetty teoria on pragmadialektinen argumen- taatioteoria (ks. van Eemeren \& Grootendorst 1992, 2004; suomeksi Leiwo \& Pietikäinen 1996; Hietanen 2012). Se lähestyy vuorovaikutusta puheaktiteorian kautta ja kuvaa erityisesti sitä, kuinka rationaalisuus muodostuu kriittisessä keskustelussa. Myös laajennetun pragmadialektisen teorian kehykseen kuuluva strategisen luovinnan (strategic maneuvering) ${ }^{1}$ käsite nousee esiin useassa luvussa. Laajennetun pragmadialektisen teorian lähtökohtana on käsitys, että argumentatiivisen keskustelun osallistujalla on kaksi tavoitetta, joita tämä pyrkii samanaikaisesti toteuttamaan: yhtäältä keskustelun säilyttäminen järkevänä, toisaalta erimielisyyden ratkaiseminen osallistujan omaksi parhaaksi mahdollisimman vähällä vaivalla. Strateginen luovinta viittaa siis näihin jatkuviin pyrkimyksiin säilyttää järkevyyden ja tehokkuuden välinen tasapaino. (Van Eemeren 2010: 39-40.)

Pragmadialektiikkaan ja muuhun argumentaatioteoriaan on yhdistetty myös kielentutkijoille tutumpia lähestymistapoja ja teorioita, kuten diskurssianalyysia, genreanalyysia, keskustelunanalyysia, korpuslingvistiikkaa ja systeemis-funktionaalista suhtautumisen teoriaa. Teoreettisten lähtökohtien ja metodologioiden kirjo näkyy paitsi eri lukujen välillä myös lukujen sisällä: analyysit ovat monimenetelmäisiä ja lähestymistavaltaan omaperäisiä.

Myös teoksen aineistot ovat monipuoliset. Mukana on institutionaalista ja vapaamuotoista keskustelua, verkossa julkaistuja tiedotteita, poliittisia puheita, televisiokeskusteluja sekä pila- ja mainoskuvia. Aineistot edustavat tasavertaisesti

1. Suomennos on Lehtoselta (2016: 40). Hietanen (2012: 210) käyttää suomennosta strateginen navigointi. 
sekä puhuttua kieltä että kirjoitettuja tekstejä. Lisäksi kahden luvun aineistona on kuvia. Kielistä edustettuina ovat englanti, espanja, italia, hollanti, ranska ja turkki.

Ilien laatimassa johdannossa on lyhyt katsaus erilaisiin argumentaatioteorioihin sekä teoksen tavoitteiden esittely. Heti alussa esiin nostetaan se, että vaikka argumentointi on luontaista kaikelle viestinnälle ja argumentaatiota on tutkittu kauan, empiirisiin aineistoihin perustuvaa tutkimusta on tehty verrattain vähän. Teos pyrkii paikkaamaan tätä puutetta asettamalla esimerkiksi seuraavanlaisia kysymyksiä: Mitkä ovat argumentaation funktiot tai päämäärät diskursiivisessa vuorovaikutuksessa? Onko kyse tiedon tuottamisesta, suostuttelusta vai jostakin muusta? Millä tavoin argumentointistrategiat vaihtelevat toimintayhteisöittäin?

\section{Teoksen teoreettinen osa}

Teoksen ensimmäinen, argumentoinnin teoriaan keskittyvä osa alkaa Michel Dufourin luvulla "Uncontroversial arguments". Siinä Dufour argumentoi sellaisia nykyisiä argumentaatioteorioita vastaan, joissa väitetään, että argumentointi perustuu aina erimielisyyteen. Dufour perustaa näkemyksensä ensinnäkin käsitteiden dialoginen ja dialektinen väliseen eroon. Vaikka niitä käsitellään usein synonyymisinä, dialogi on Dufourin mukaan rauhallista ja yhteistyöhön perustuvaa toimintaa, kun taas dialektiikka on riidanhaluista. Niinpä argumenttien vaihto voi olla dialogista olematta dialektista. Tämän lisäksi Dufour esittää, että on olemassa argumentteja, jotka eivät perustu osallistujien erimielisyyteen. Vaikka jokaiseen näkemykseen olisikin mahdollista kuvitella vastaväittäjä, todellisuudessa aina tällaista ei ole. Näin voi olla esimerkiksi, kun joku esittää vahvasti kenttä- tai tieteenalasidonnaisia argumentteja ihmisille, jotka eivät ole kyseisen alan asiantuntijoita tai joilla ei ole mielipidettä kyseiseen näkemykseen.
Toisessa luvussa "Connection premises: Their character, criticism, and defence" Jan Albert van Laar tarkastelee argumentin premissien ja johtopäätöksen välisen linkin riittävyyden ja sopivuuden arviointia. Kun argumentin esittäjä sitoutuu argumentin premissien ja johtopäätöksen yhteyden riittävyyteen, keskeinen kysymys on, mikä tämä yhteys on ja milloin se on riittävä. Van Laar lähestyy kysymystä dialektisen tarkastelutavan näkemysten ja tekniikoiden avulla ja esittää, että premissien ja johtopäätöksen yhteyden puolustus voi nojata yhtäältä puhetilanteeseen, toisaalta sen taustalla olevaan yleisempään sääntöön. Oleellista on, että yhteyden riittävyys on aina riippuvainen kontekstista ja dialogin osallistujista.

Kolmannessa luvussa "Argumentative and non-argumentative rhetorical content: Two examples in same-sex marriage discourse" Lilian Bermejo-Luque erottelee toisistaan argumentatiivisen ja eiargumentatiivisen retorisen sisällön, joita kumpaakin löytyy kaikesta viestinnästä. Tätä eroa Bermejo-Luque havainnollistaa analysoimalla kahta esimerkkiä, joissa keskustellaan samaa sukupuolta olevien avioliitosta. Hän osoittaa, että argumentointi voidaan toteuttaa myös implisiittisesti: lukijalle tarjoillaan todistusaineistoa, joka ikään kuin puhuu puolestaan - johtopäätöksen voi jättää kielentämättä.

\section{Argumentointikäytänteet poliittisissa ja oikeudellisissa konteksteissa}

Teoksen toisessa osassa analysoidaan argumentointikäytänteitä poliittisissa konteksteissa. Osan ensimmäisessä luvussa "Questioning the questionable: Arguments and counter-arguments in political accountability interviews" Ilie tarkastelee kysymys-vastaus-rakenteen strategisia käyttöjä ja argumentatiivisia funktioita sekä keskeisten sanojen määrittelyä poliitikon televisiohaastattelussa. Pragmaretorisen lähestymistavan avulla tarkas- 
tellaan haastattelijan käyttämien erityylisten kysymysten fokusta, laajuutta ja haastavuutta ja toisaalta sitä, kuinka usein haastateltavat asettuvat haastamaan kysymyksen lähtökohtia tai kiertämään ne. Kun haastattelija ja haastateltava eivät jaa samoja oletuksia käsiteltävänä olevista asioista, heidän voi nähdä suuntaavan näkemyksensä erilaisille yleisöille. Erityisen kiinnostavaa luvussa on sen tarkastelu, miten haastattelija ja haastateltava määrittelevät keskeisiä tapahtumia eri tavalla esimerkiksi nimeämisen kautta: haastattelija nimittää tiettyä tapahtumaa "Krimin haltuunotoksi" (annexation of Crimea), kun taas haastateltava puhuu "Krimin liittymisestä Venäjään" (Crimea joining the Russian Federation).

Manfred Kienpointnerin kirjoittamassa luvussa "Reason and passion in political rhetoric: The case of Louise Michel's (1830-1905) revolutionary discourse" tarkastellaan ja arvioidaan Louise Michelin poliittista retoriikkaa. Michel oli ranskalainen anarkisti, joka luennoi sosialismista ja lietsoi luokkasotaa. Aristoteleen klassisen kolmijaon mukaisesti Kienpointner tarkastelee sitä, miten onnistuneesti Michelin puheissa ja kirjoituksissa yhdistyivät logos, ethos ja pathos. Retoriikan tutkimukseen yhdistetään kriittistä diskurssianalyysia ja pragmadialektiikkaa, erityisesti strategisen luovinnan käsitettä. Käsitettä käytetään kuvaamaan sitä, miten onnistuneesti Michel yhdistää retorista tehokkuutta ja argumentoinnin standardeita - eli miten hän onnistuu tasapainoilemaan tehokkuuden ja järkevyyden vaatimusten välillä. Argumenttien analyysi osoittaa, että Michelin ethos ja pathos toimivat, mutta argumentit osittain ontuvat. Analyysi paljastaa argumenteista heikkouksia, kuten vääriä dilemmoja, virheellisiä kausaalisuhteita ja kyseenalaisia analogioita.

Osan kolmannessa luvussa "Interpersonal style(s) in diplomatic argumentation online: A study of argument schemes and evaluation in press releases of UNSC permanent members" Elizabeth Swain tarkastelee viiden valtion (Ison-Britannian, Kiinan, Ranskan, Venäjän ja Yhdysvaltojen) ulkoministeriöiden verkkosivuilla julkaistuja tiedotteita. Analysoitavana on se, toimivatko kansainvälisesti jaetut, subjektiivisuutta säätelevät konventiot edelleen nykyisessä globaalissa verkkokontekstissa vai ovatko valtiot kehittäneet näistä poikkeavia lähestymistapoja omien kantojensa puolesta argumentointiin. Swain yhdistää kvantitatiivista ja kvalitatiivista analyysia ja käyttää työkaluinaan Waltonin, Macagnon ja Reedin (2008) argumenttiskeemoja sekä Martinin ja Whiten (2005) suhtautumisen teoriaa. Argumenttiskeemat ovat abstrakteja malleja ihmisten päättelystä, ja ne jaetaan kolmeen kategoriaan: lähteisiin, sääntöihin ja käytännölliseen päättelyyn perustuviin. Swainin aineistossa hallitukset valitsevat monenlaisia skeematyyppejä, vedoten esimerkiksi lakiin, moraaliin, ennakkotapauksiin, auktoriteetteihin tai myötätuntoon. Analyysi osoittaa, että eri valtioiden välillä on eroja siinä, mitä skeemoja ja suhtautumisen vaihtoehtoja käytetään. Esimerkiksi Kiinalla painottuu autoritaarisuus, Ranskalla ihmisoikeuksiin ja tunteisiin vetoaminen, Venäjällä negatiiviset lähdettä arvioivat argumentit ja sosiaalinen hyväksyntä ja Yhdysvalloilla huolipuhe. Nämä vaihtelevat valinnat rakentavat eri tavoin hallituksia ja niiden yleisöä sekä kuvastavat argumentoinnin aihetta ja sitoutumisen astetta.

Teoksen kolmas osa keskittyy analysoimaan argumentointia oikeudellisissa konteksteissa. Aluksi Giuliana Garzone käsittelee luvussa "The interpreter-mediated police interview as argumentative discourse in context: A case-study" tulkkivälitteistä poliisikuulustelua argumentatiivisena toimintatyyppinä. Garzonen tavoite on osoittaa, että poliisikuulustelulla on argumentatiivinen luonne, vaikkei sitä heti huomaisikaan ja vaikkei sitä ole juurikaan huomioitu kirjallisuudessa. Tutkimus 
asettuu monimetodiseen diskurssianalyysin kehykseen ja hyödyntää genreanalyysin, keskustelunanalyysin ja pragmatiikan näkemyksiä. Argumenttien rekonstruointi ja analyysi perustuu pragmadialektiseen argumentointiteoriaan. Garzonen löydökset osoittavat, että jollei kuulusteltava alun perin myönnä häntä kohtaan esitettyjä syytöksiä, poliisikuulustelu on luontaisesti argumentatiivinen kielenkäyttötilanne, jossa jännitteenä on kuulustelijan ja kuulusteltavan välinen näkemysero. Tällöin kuulustelijan tavoite on todistaa syytökset kyselyprosessin avulla. Epäilty puolestaan yrittää kumota ne kokonaan tai osittain.

Osan toisessa luvussa "Context and genre in judicial argumentation: A casestudy" Francesca Santulli tarkastelee kontekstin roolia juridisten tekstien tuottamisessa sekä oikeuden tuomioita genrenä, johon liittyy omanlaisiaan argumentatiivisia ja tekstuaalisia piirteitä. Analyysissa yhdistetään frekvenssejä, avainsanahakuja ja konkordansseja diskurssianalyyttiseen argumenttien tarkasteluun. Frekvenssilistat ja avainsanahaut mahdollistavat tekstien vertailun, ja konkordansseista on hyötyä, kun tarkastellaan, miten toistuvia, aiheen kannalta merkittäviä sanoja tai ilmauksia käytetään. Kvalitatiivisen analyysin avulla taas tarkastellaan argumenttien valintaa ja järjestystä. Analyysi osoittaa, ettei tuomari tuo keskusteluun uusia argumentteja vaan tarkastelee ja arvioi aiempia argumentteja; kyse on siis tavallaan toisen asteen argumentoinnista ja meta-argumentatiivisen tekstin tuottamisesta.

\section{Argumentointikäytänteet institutio- naalisissa ja arkisissa väittelyissä sekä multimodaalisissa ympäristöissä}

Teoksen neljännessä osassa analysoidaan institutionaalisia ja arkisia väittelyitä. Osan aloittaa Paola Catenaccion luku "Caught between profitability and responsibility: Arguing legitimacy in the pharmaceutical industry", jossa kuvataan 2000-luvun alun AIDS/HIV-lääkekiistassa käytettyjä argumentoinnin strategioita. Kiistassa oli kyse siitä, voidaanko yritysten taloudelliset oikeudet ohittaa ihmisoikeuksien nimissä: 39 lääkeyhtiötä nosti haasteen Etelä-Afrikan hallitusta vastaan, kun se oli hyväksynyt lain, jolla markkinoille voitiin tuoda halpoja lääkkeitä hillitsemään AIDS-epidemiaa. Aineistona on lehdistötiedotteita, raportteja, uutisia ja oikeudenkäyntidokumentteja. Tutkimus yhdistää pragmadialektista argumentaatioteoriaa ja diskurssianalyysia yhtäältä argumenttien ja niiden premissien rekonstruointiin, toisaalta retoristen valintojen tehokkuuden arviointiin. Analyysi osoittaa esimerkiksi, miten kiistan molemmat osapuolet käyttivät strategista luovintaa yrittäessään rakentaa yhteistä maaperää yleisönsä kanssa. Luovinta ilmeni esimerkiksi vetoamisena universaalisti hyväksyttyihin arvoihin kuten ihmisoikeuksiin ja tieteen kehitykseen.

Luvussa "Multi-participant TV debate as an argumentative activity type" Yeliz Demirin tavoite on kuvata monenkeskinen televisioväittely argumentatiivisena toimintatyyppinä (ks. van Eemeren \& Houtlosser 2005). Teoreettisena ja metodologisena kehyksenä on jälleen pragmadialektinen argumentaatioteoria. Monenkeskisen televisioväittelyn argumentatiivinen kuvaus koostuu ensinnäkin institutionaalisten rajoitteiden kuvauksesta. Toisena keskustelusta erotellaan kriittiseen keskusteluun kuuluvat neljä osaa: lähtötilanne, proseduraaliset ja materiaaliset lähtökohdat, argumentoinnin keinot ja mahdollinen lopputulos. Lähtötilanne käsittää erot osallistujien mielipiteissä, kun taas proseduraalisiin ja materiaalisiin lähtökohtiin kuuluvat juonnetun televisioväittelyn normisto ja konteksti. Argumentoinnin keinoihin kuuluvat mielipidettä ilmaisevat väitteet sekä faktoille ja todisteille perustuvat argumentit. Lopputuloksena on usein se, etteivät mielipiteiden erot ratkea - väittelystä palataan takaisin lähtötilanteeseen. 
Osan kolmannessa luvussa "The transmission of what is taken for granted in children's socialization: The role of argumentation in family interactions" Antonio Bova, Francesco Arcidianco ja Fabrice Clément analysoivat argumentointia perheenjäsenten välisissä pöytäkeskusteluissa. Videomuotoista aineistoa on kerätty sekä Italiasta että Sveitsistä. Argumentaation rakenteen analyysissa hyödynnetään pragmadialektiikan lisäksi Rigottin ja Greco Morasson (2010) argumenttimallia. Luku osoittaa, että argumentaation implisiittiset taustaoletukset ovat tehokas keino käsitellä yhteisön arvoja ja normeja itsestäänselvyyksinä ja siirtää niitä sukupolvelta toiselle.

Teoksen viimeinen osa keskittyy multimodaalisiin argumentointikäytänteisiin. Luvussa "Visual arguments in activists' campaigns: A pragmadialectical perspective" Chiara Degano pohtii, ovatko visuaaliset argumentit mahdollisia. Tutkimusaineistona on Amnestyn ja Greenpeacen verkossa julkaistuja multimodaalisia kampanjamainoksia. Kuvien analyysissa yhdistetään Kressin ja van Leeuwenin (2006 [1996]) visuaalisen suunnittelun kielioppia ja pragmadialektista argumentaatioteoriaa. Degano rekonstruoi vakuuttavasti esimerkiksi Pekingin olympialaisia kritisoiviin kuviin sisältyvät argumentit ja osoittaa, mihin ristiriitaisuuksiin ja olettamuksiin niiden teho perustuu. Luku osoittaa havainnollisesti, että myös kuvat voivat olla argumentteja.

Viimeisessä luvussa "Attacks on the cartoonist's strategic manoeuvring: An argumentative analysis of criticism on political cartoons" H. José Plug tarkastelee pragmadialektisesti poliittisia pilakuvia ja niiden saamaa kritiikkiä. Pilapiirtään tasapainottelua järkevyyden ja tehokkuuden vaatimusten välillä kuvataan strategisen luovinnan käsitteellä: piirtäjä pyrkii samaan aikaan olemaan järkevä ja tehokas. Plug tulee tulokseen, että poliittiseen pilapiirrokseen kohdistuva kritiikki voi koskea kolmea asiaa: visuaalisen metaforan valintaa, näkökulmaa, josta poliitikon käytöstä arvioidaan, tai argumenttia, jossa poliitikon käytöstä kuvaillaan negatiivisesti.

\section{Lopuksi}

Ilien ja Garzonen teos tarjoaa tuoreita ja monipuolisia näkökulmia argumentaation teorioihin ja analyysiin. Esimerkiksi pragmadialektisen argumentaatioteorian hyödyntäminen on fennistin näkökulmasta kiinnostava lähestymistapa sikälikin, että fennistiikassa argumentaation ja retoriikan tarkastelu on usein nojannut lähinnä perelmanilaiseen uuteen retoriikkaan (Perelman 1996; fennistiikassa ks. kootusti Mäntynen \& Sääskilahti 2012). Teoksen aineistot ovat kiinnostavia, ja niiden analyysi on jokaisessa luvussa selkeää.

Teoksen jaottelu kontekstien tai diskurssiympäristöjen mukaan toimii joissakin osissa paremmin kuin toisissa. Pakoin, esimerkiksi neljännessä osassa, yhteys eri lukujen välillä jää melko löyhäksi. Vaikka aineistot on hahmotettavissa jollakin tapaa samaan diskurssiympäristöön, eroavat ne paljon toisistaan (esim. tv-väittely vs. arkinen pöytäkeskustelu). Toisaalta taas viides, multimodaalista argumentointia käsittelevä osa muodostaa varsin yhtenäisen kokonaisuuden.

Artikkelikokoelma tarjoaa näkökulmia tämänhetkisiin argumentointia hyödyntäviin kielenkäytön muotoihin, argumentoinnin harjoittamiseen sekä monitasoisiin vaihteluihin argumentaation strategioissa ja tavoissa. Teos osoittaa havainnollisesti, miten argumentoinnin rakenteet ja strategiat ovat sidoksissa toimintayhteisöihin ja miten monialaisesta ilmiöstä argumentoinnissa on kyse. Lisäksi teos tarjoaa käytännönläheisiä näkökulmia siihen, miten argumentaatiota voi tarkastella erilaisista aineistoista ja erilaisin metodein. Niinpä teosta voi suositella sekä ammattitutkijoille että opiskelijoille. 
Se kiinnostanee paitsi kielentutkijoita ja filosofeja myös esimerkiksi politiikan ja median tutkijoita.

$$
\begin{array}{r}
\text { EMMI LAHTI } \\
\text { etunimi.sukunimi@helsinki.fi } \\
\text { Kirjoittaja on suomen kielen väitöskirja- } \\
\text { tutkija Helsingin yliopistossa. }
\end{array}
$$

\section{Lähteet}

Eemeren, Frans H. van 2010: Strategic maneuvering in argumentative discourse. Extending the pragma-dialectical theory of argumentation. Amsterdam: John Benjamins Publishing Company.

Eemeren, Frans H. van - GrootenDorst, RoB 1992: Argumentation, communication, and fallacies. A pragmadialectical perspective. Hillsdale, NJ: Lawrence Erlbaum Associates.

- 2004: A systematic theory of argumentation. The pragma-dialectical approach. Cambridge: Cambridge University Press.

Eemeren, Frans H. van - Houtlosser, PETER 2005: Theoretical construction and argumentative reality. An analytic model of critical discussion and conventionalised types of argumentative activity. - David Hitchcock \& Daniel Farr (toim.), The uses of argument. Proceedings of a conference at McMaster University, 18-21 May 2005 s. 75-84. Hamilton, Ontario: Ontario Society for the Study of Argumentation.

Hietanen, Mika 2012: Pragmadialektiikka - 25 vuotta puolesta ja vastaan. - Juho Ritala (toim.), Tutkimuksia argumentaatiosta s. 207-226. Turku: Turun yliopisto.

Kress, Gunther - van Leeuwen, Theo 2006 [1996]: Reading images. The gram- mar of visual design. Toinen painos.

Lontoo: Routledge.

Lehtonen, Juha 2016: Viisiportaisen menetelmän kehittäminen kuvallistekstuaalisen argumentaation analysoimiseksi pragma-dialektisessa viitekehyksessä. Esimerkkianalyyseinä kolme Oikeutta Eläimille -järjestön Facebooktilapäivitystä. Filosofian pro gradu -tutkielma. Jyväskylän yliopisto.

Leiwo, Matti - Pietikäinen, Sari 1996: Kieli vuorovaikutuksen ja vallankäytön välineenä. - Kari Palonen \& Hilkka Summa (toim.), Pelkkää retoriikkaa s. 85-108. Tampere: Vastapaino.

Martin, J. R. - White, P. R. R. 2005: The language of evaluation. Appraisal in English. Basingstoke: Palgrave MacMillan.

Mäntynen, Anne - SÄÄskilahti, Minna 2012: Uusi retoriikka genrejen tutkimuksessa. - Vesa Heikkinen, Eero Voutilainen, Petri Lauerma, Ulla Tiililä \& Mikko Lounela (toim.), Genreanalyysi - tekstilajitutkimuksen käsikirja s. 194-207. Helsinki: Gaudeamus.

Perelman, Chaïm 1996: Retoriikan valtakunta. Suomentanut Leevi Lehto. Vastapaino: Tampere.

Rigotti, Eddo - Greco Morasso, Sara 2010: Comparing the argumentum model of topics to other contemporary approaches to argument schemes. The procedural and material components. - Argumentation 24 S. 489-512.

Walton, Douglas - Macagno, FabriZIO - ReED, Chris 2008: Argumentation schemes. Cambridge: Cambridge University Press.

Wenger, Etienne 1998: Communities of practice. Learning, meaning, and identity. Cambridge: Cambride University Press. 